\section{Still dirty after all these years}

\section{Sydney}

DESPITE earlier clean-up attempts, plutonium still contaminates the Maralinga ('Fields of Thunder') test site, northwest of Adelaide, which was used by the British during the $1950 \mathrm{~s}$ and early 1960 s for above-ground nuclear bomb tests. According to a report that will be tabled in the Australian parliament later this session, complete removal of the remaining radioactivity could cost as much as $\mathrm{A} \$ 600$ million, a sum towards which the British government may be asked to contribute.

Following a recommendation in 1985 by a Royal Commission that Maralinga should be cleaned up and returned to its original inhabitants, the Pitjinjara aborigines, a Technical Assessment Group (TAG) was set up in February 1986 by the federal Department of Minerals and Energy to assess the level of contamination and estimate the cost of decontamination. The TAG was a joint AngloAustralian venture, with independent representation from the United States.

The TAG identified an area of 95 square kilometres over which radioactivity levels due to plutonium were five times greater than the internationally recognized 1 millisievert (mSv) safety standard. According to the executive summary of the TAG report, which was leaked to an Australian television network, full decontamination of the affected area would require collection and reburial of soil, and would cost $A \$ 600$ million. Less expensive but less thorough options described by the TAG include ploughing to dilute the surface soil, or overlaying the present surface and increasing security around the site. The present system of security fences costs $A \$ 7$ million a year to maintain.

According to Rob Robotham, director of safety and health management at the University of Melbourne and author of a book on Maralinga, the sums of money being considered for clean-up would be better spent elsewhere. He says that if there were 1,000 people living on the site the added health risk, chiefly from inhalation of dust and ingestion of plants and animals contaminated with plutonium, would amount to one case of cancer, probably of the lung, in 20 years.

Complicating the debate over what should be done is the question of who should pay. In 1967, the Australian government released the British from further liability after they had completed 'Operation Brumby', in which contaminated areas in the vicinity of large explosions were cleaned up. But according to Robotham, the British neglected areas affected by what were deemed "minor tests". He also says that breaking up the soil, which the British thought would solve contamination problems, in fact spread it around.

\section{IMAGE UNAVAILABLE FOR COPYRIGHT REASONS}

Explosion at Maralinga in 1957. The device was suspended 1,500 feet in the air. (AP)

Jim McClelland, the judge who was in charge of the Royal Commission that recommended clean-up, says the British have a responsibility to return Maralinga to a habitable state. He says that when Harold Holt [then prime minister] released the British government from further responsibility, he "didn't have all the information about the extent of the plutonium dispersal. There is now a legal and an overwhelming moral obligation on the part of the British to clean the place up." The British High Commissioner, however, responded with the statement that "Mr McClelland can say what he likes...it's a matter for the Australian government".

Tania Ewing

\section{RABIES VACCINE}

\section{Washington}

THE first field tests of a genetically engineered rabies vaccine are at long last under way in the United Stites - some four years after field tests were conducted in Canada and months after a full-scale campaign to eradicate rabies from the fox population began in France. Cumbersome regulatory processes in the United States Warren B. Cheston, associate director of the Wistar Institute which helped develop the vaccine.

Rabies is now at epidemic proportions in the raccoon population in the mid-Atlantic states and there are fears it could spread to domestic animals, including pet cats and dogs. The vaccine is a recombinant vaccinia-virus vaccine and is the product of collaborative research between the Wistar Institute of Philadelphia and Transgene of Strasbourg, France.

Trials are being carried out on the uninhabited Parramore Island off the Virgiare to blame for the delay, according to

Japan to help China to clean up Tokyo

$J_{\text {APAN will help China to fight its chronic }}$ pollution problems by providing Overseas Development Aid (ODA) to build an environment research institute in Beijing, said an official at Japan's Environment Agency last week. The idea of an ODAfunded institute was first proposed by China in 1988, but Japan suspended discussions after the military crackdown in Beijing in June last year. At the recent summit of Western nations in Houston, Texas, however, Japan won an understanding to resume aid to China, opening the way for renewed discussions on the institute.

In a meeting in Beijing last month, Japan agreed to provide $¥ 10,000$ million ( $\$ 67$ million) for the institute, subject to approval by Japan's Ministry of Finance, and to transfer antipollution technology from Japan. Construction of the institute will begin in the second half of next year and is expected to be completed in 1994, according to an environment agency official.

China has severe pollution problems. In particular, emission of sulphur dioxide from coal-burning is believed to be causing acid rain to fall as far afield as the west coast of Japan (see Nature 340,$671 ; 1989$ ). Japan will provide China with technology and expertise to reduce such emissions, but details of the activities of the institute will not be decided until another meeting between Japanese and Chinese officials later this year, according to an official of the grant-aid division of the Ministry of Foreign Affairs.

David Swinbanks

\title{
Better late than never for start of tests
}

nia coast. The vaccine is placed in a bait containing fish oils that are abhorrent to man and other animals but attractive to raccoons. Blood tests will be carried out for up to a year on raccoons to determine the level of protection against rabies.

Federal approval for the field test, which was originally to have taken place in South Carolina, was granted by the US Department of Agriculture (USDA) in March 1989, but Wistar failed to obtain the approval of the South Carolina public health authorities. It then moved the project to Parramore Island, and received approval in July 1989. A further year was consumed by negotiations with the Nature Conservancy which owns the island.

Jane Rissler, spokeswoman for the National Wildlife Federation, said that it was only when the Nature Conservancy became involved that "the protocol finally came up to the science and safety standards that the USDA should have imposed".

Diane Gershon 